\title{
A Mathematical model for the cold storage of agricultural products ${ }^{1}$
}

\author{
Modelo matemático de câmara fria para armazenamento de produtos agrícolas
}

\author{
Carlos Renato Meneghetti²*, Alexandre Tizzei², Nelson Luis Cappelli ${ }^{3}$, Claudio Kiyoshi Umezu ${ }^{3}$ e Guilherme \\ Bezzon $^{2}$
}

\begin{abstract}
Studies of control strategies for refrigeration systems observe, among other variables, the dynamic behavior of temperature and the consumption of electrical energy. Aiming to contribute to these studies, this work presents the proposal and validation of a mathematical model for the cooling system of a cold-storage unit. The model approximates the dynamics and interdependence of the variables, to first-order systems with time delay and the summation of effects. The input variables available are the frequency of compressor activation and the thermal load imposed on the unit, and as output variables, the air temperature both at the evaporator inlet and at the centre of the chamber, as well as the electrical power consumed by the compressor. The results obtained were satisfactory, with an error of less than $0.11{ }^{\circ} \mathrm{C}$ for the air temperature at the evaporator inlet, of less than $0.09{ }^{\circ} \mathrm{C}$ for the temperature at the centre of the chamber, and of less than $1 \%$ for the electrical energy consumed.
\end{abstract}

Key words: Variable rotation. Simulation. Agricultural products-storage. Electrical energy-consumption.

RESUMO - Os estudos de estratégias de controle para sistemas de refrigeração observam, entre outras variáveis, o comportamento dinâmico da temperatura e da energia elétrica consumida. Com o objetivo de contribuir com estes estudos, o presente trabalho apresenta a proposta e a validação de um modelo matemático do sistema de refrigeração de uma câmara fria. $\mathrm{O}$ modelo aproxima a dinâmica e a interdependência das variáveis a sistemas de primeira ordem com tempo de atraso e somatória de efeitos. Como variáveis de entrada tem-se a frequência de acionamento do compressor e a carga térmica imposta à câmara e como variáveis de saída as temperaturas do ar na entrada do evaporador e no centro da câmara, bem como a potência elétrica consumida pelo compressor. Os resultados obtidos foram satisfatórios, com erro menor que $0,11^{\circ} \mathrm{C}$ para a temperatura do ar na entrada do evaporador, menor que $0,09^{\circ} \mathrm{C}$ para a temperatura do ar no centro da câmara e menor que $1 \%$ para energia elétrica consumida.

Palavras-chave: Rotação variável. Simulação. Produtos agrícolas-armazenamento. Energia elétrica-consumo.

\footnotetext{
*Autor para correspondência

${ }^{1}$ Recebido para publicação em 19/10/2011; aprovado em 11/07/2012

Parte da Dissertação de Mestrado do primeiro autor, apresentada ao Programa de Pós-Graduação em Engenharia Agrícola da Universidade Estadual de Campinas/UNICAMP, pesquisa financiada pelo $\mathrm{CNPq}$

${ }^{2}$ Centro Universitário Salesiano de São Paulo/Unisal, Campinas-SP, Brasil, 13.087-290, crmeneghetti@ibest.com.br, tizzei@ibest.com.br, guilherme@sj.unisal.br

${ }^{3}$ Faculdade de Engenharia Agrícola-Feagri/Unicamp, Campinas-SP, Brasil, 13.083-875, cappelli@ feagri.unicamp.br, umezu@ feagri.unicamp.br
} 


\section{INTRODUCTION}

Typically agricultural products are subjected to various post-harvest processes, especially fruits and vegetables. Among these processes, cooling and cold storage contributes to its quality and longevity. Chitarra and Chitarra (2005) established that the best temperatures for storage are between 0 to $15^{\circ} \mathrm{C}$, depending on the product. Also, mention that cooling is important to decrease metabolism and that every $10^{\circ} \mathrm{C}$ less, the metabolic reactions fall by half, especially for highly perishable products.

After cooling, products must be stored in cold storage for preservation. A failure in cold chain causes lower durable products and inefficient use of energy for cooling and storage. According to Cortez, Honório e Moretti(2002), when cold is interrupted, it can create gaps for deterioration due to water condensation on the product, providing an excellent environment for fungi growth and other microorganisms.

Thus, during the storage period, it is interesting to keep the chamber temperature in a narrow range and no major variation, in spite of the existence of disturbances, such as heat generation due: the biological activity, the operation of electric motors of the evaporator; presence of operators, the heat loss through walls, floor and roof and heat losses due to eventual opening of the chamber, among others.

The control strategy of on-off type, normally used in these chambers, causes premature deterioration of the compressor, high consumption of electricity and permanent unwanted oscillations in the chamber temperature.

The temperature control by varying the compressor speed has emerged as an interesting alternative for reduction in energy consumption, equipment preservation and, also, to keep the control of the chamber temperature, maintaining the quality and longevity of stored products. Several scientific papers (CUEVAS; LEBRUN, 2009; EKREN; SAHIN; ISLER., 2010; HUA; JEONG; YOU, 2008; MENEGHETTI et al., 2010; QURESHI; TASSOU, 1996) show the benefits of this type of control which increases performance and decreases power consumption.

Obtaining a numerical model that adequately describes the dynamic behavior of such systems is crucial to simulate and explore their behavior in order to develop new strategies for temperature control. Some studies use numerical models based on partial differential equations for the conservation of mass and energy, dividing the system into control volumes (COSTA; LEAL; CARMO JÚNIOR, 2004; LI; ALLEYNE, 2010; MACKINLEY; ALLEYNE, 2008; NOGUEIRA; ZÜRN, 2005; ZHAO; ZAHEERUDDIN, 2005), obtaining important results for the simulation of the transient in cooling systems. Pirozzi and Amendola (2005) applied simulation to explore the rapid cooling of strawberries with forced air, validating the model with experiments, obtaining results that reinforce the importance of numerical models. However, an efficient model with simple identification makes easier its use and application, saving time and resources.

Studies of new control strategies generally intend to reduce the fluctuation of the controlled environment temperature and often reduce energy consumption associated with the system operation. In this sense, a numerical model is extremely useful for the simulation of the dynamic behavior of temperature and can estimate the electrical power consumed. Studies, as presented by Silva (2003) indicate that the compressor is responsible, on average, for $92 \%$ of electricity consumption of the refrigeration system. This fact reinforces the importance of studies that address the control of this equipment.

In this context, the objective of this study is to present an empirical numerical model for simulation of refrigeration systems with variable compressor speed operating under load disturbances.

\section{MATERIAL AND METHODS}

The system under study operates in the storage phase, around a predetermined point, and may be considered continuous, time-invariant and with concentrated parameters. Thus, it can be represented by Laplace transfer functions.

Aprea and Renno (2001), Aprea and Renno (2009), and Ding (2006) reported that it is possible to relate the transfer function of mass of the refrigerant which passes through the evaporator with the air temperature at its output to a first order system with time delay - Equation 01, where: $\mathrm{K}$ is the static sensitivity; $\mathrm{L}$ is the time delay and $\mathrm{T}$ is the time constant.

$$
G(s)=\frac{K e^{-L_{s}}}{T s+1}
$$

Hua, Jeong and Yoon(2007) also used first-order approximation with a time delay for the models involved in thermal systems and obtained satisfactory results in their simulations.

Morini and Piva $(2007,2008)$ described the use of computer simulation of the dynamic behavior of thermal systems. They mention it is possible to separate the system into discrete blocks with relatively simple equation and still achieve significant results in computer simulations.

The model proposed intends to represent the dynamic behavior of temperature and electric power consumed by the compressor in a cold chamber at the stage of storage of 
perishable agricultural products. Therefore, the system shall be subject only to minor disturbances and modifications in the compressor, condenser, evaporator, and pipes are not necessary. Also, it was kept the original expansion valve, without electronic control, since studies like Hua, Jeong and Yoon. (2007) found little influence of the expansion valve control in the temperature of the controlled environment.

The numerical model proposed is presented in Figure 1. Input variables are: $F(s)$ which is the frequency of the compressor drive motor in Hertz and $\mathrm{C}$ (s) representing the heat load applied to the system, in Watts. The output parameters are: $\mathrm{Te}(\mathrm{s})$ that corresponds to the temperature of air entering in the evaporator; $\mathrm{Tc}(\mathrm{s})$ as the air temperature in the chamber center, expressed in ${ }^{\circ} \mathrm{C}$ and, finally, $\mathrm{P}(\mathrm{s})$ representing the electrical power, in Watts, consumed by the compressor.

Increasing $\mathrm{F}(\mathrm{s})$, among other effects, reduces the air temperature inside the chamber and increases the power consumed by the compressor. Then, the blocks $\mathrm{G}_{\mathrm{F}_{-T e}}(\mathrm{~s}), \mathrm{G}_{\mathrm{F}_{-} \mathrm{Tc}}(\mathrm{s})$ and $\mathrm{G}_{\mathrm{F}_{\mathrm{P}}}(\mathrm{s})$ represent the influence of $\mathrm{F}(\mathrm{s})$ in their respective output variables $\mathrm{Te}(\mathrm{s}), \mathrm{Tc}(\mathrm{s})$ and $\mathrm{P}(\mathrm{s})$. Therefore, their transfer functions can be written according to Equations 2, 3 and 4:

Figure 1 - Blocks diagram for the proposed model

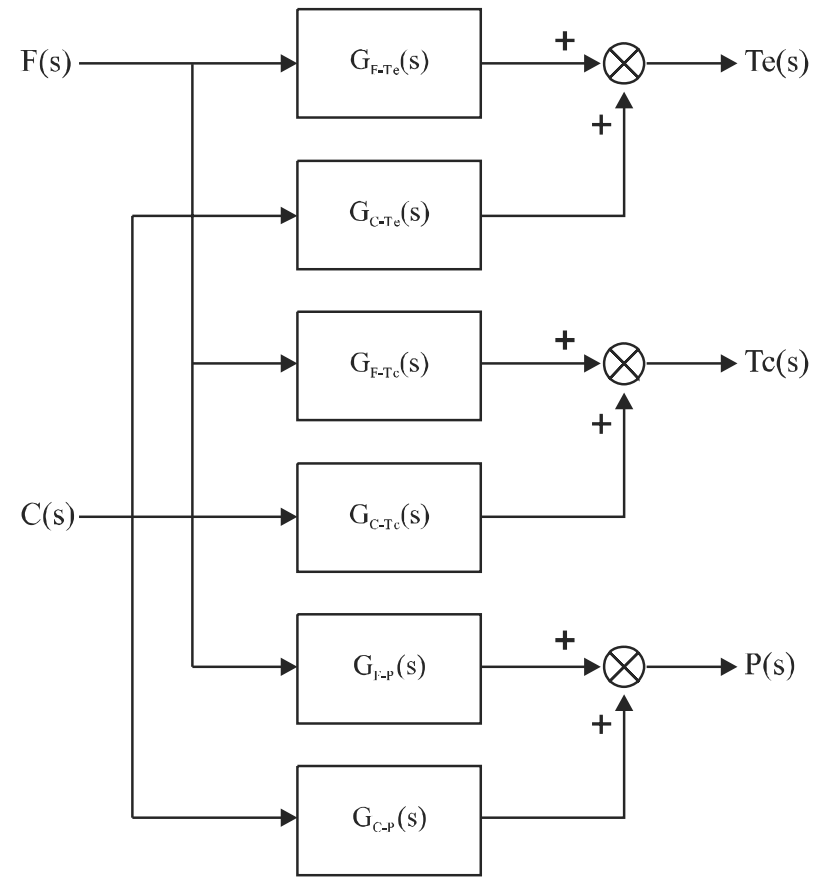

$$
G_{F-T_{e}}(s)=\frac{T_{e}(s)}{F(s)}
$$

$$
\begin{gathered}
G_{F-T_{C}}(s)=\frac{T_{C}(s)}{F(s)} \\
G_{F-P}(s)=\frac{P(s)}{F(s)}
\end{gathered}
$$

The stored product, yielding heat to the chamber internal environment tends to increase the internal air temperature and the electric power consumed by the compressor. Thus, the blocks $\mathrm{G}_{\mathrm{C}_{-} \mathrm{Te}}(\mathrm{s}), \mathrm{G}_{\mathrm{C}_{\mathrm{TC}}}(\mathrm{s})$ and $\mathrm{G}_{\mathrm{C} \mathrm{P}}(\mathrm{s})$ represent the influence of the heat load imposed on the system in their respective output parameters $\mathrm{Te}(\mathrm{s}), \mathrm{Tc}(\mathrm{s})$ and $\mathrm{P}(\mathrm{s})$. Their transfer functions can be written according to Equations 5, 6 and 7:

$$
\begin{aligned}
& G_{C-T_{e}}(s)=\frac{T_{e}(s)}{C(s)} \\
& G_{C-T_{C}}(s)=\frac{T_{c}(s)}{C(s)} \\
& G_{C-P}(s)=\frac{P(s)}{C(s)}
\end{aligned}
$$

For the block $\mathrm{G}_{\mathrm{F}_{\mathrm{P}} \mathrm{P}}(\mathrm{s})$, the time constant and time delay are very small compared with the values of other blocks, then the dynamics of the combination of electric motor and compressor was neglected, adopting only its static sensitivity (DING, 2006; ZHAO; ZAHEERUDDIN, 2005). The other blocks are represented by first order systems with time delay according to Equation 1.

As shown in Equations 8, 9 and 10, each output variable is the result of the sum of the effects of input variables, multiplied by their transfer functions.

$$
\begin{aligned}
& T_{e}(s)=F(s) G_{F-T_{e}}(s)+C(s) G_{C-T_{e}}(s) \\
& T c(s)=F(s) G_{F-T_{c}}(s)+C(s) G_{C-T_{C}}(s) \\
& P(s)=F(s) G_{F-P}(s)+C(s) G_{C-P}(s)
\end{aligned}
$$

The model parameters were obtained using the first method proposed by Ziegler and Nichols, also used by Aprea Renno (2001) and Zaheeruddin and Zhao (2005). Basically, this method consists in obtaining the experimental system curve response to a step type excitation in the input variable. A conventional cold storage chamber, typically applied for storage of fruits and vegetables with dimensions of $3750 \times 2750 \times 2850 \mathrm{~mm}$ was used for the experimental analysis. Its components, such as pipelines, condenser, expansion valve and evaporator were kept in their original settings, except the controller originally of on-off type. It was replaced by a control system and data acquisition. Figure 2 shows the diagram of system control and data acquisition 
used in the experiments, some showing pictures of the equipment. The system used a frequency inverter to control the compressor speed and a bank of electrical resistance to generate heat load inside the chamber. The temperature sensors were of type PT100, linked to temperature transmitters with output 4-20 mA. An electronic transducer measured the electrical power consumed by the compressor and transmitted by RS485 Modbus RTU protocol.

For the error calculation, it was used the standard deviation, according to Equation 11, where: $\mathrm{D}$ is the standard deviation; $n$ is the number of samples and $(\mathrm{Vm}-\mathrm{Ve})$ is the error between model $(\mathrm{Vm})$ and experiment $(\mathrm{Ve})$.

$$
D=\sqrt{\frac{1}{n}} \sum_{0}^{n}(V m-V e)^{2}
$$

A software developed by Tizzei et al. (2011), using LabVIEW $^{\circledR}$, running on a microcomputer, controls the
Figure 2 - Experimental device

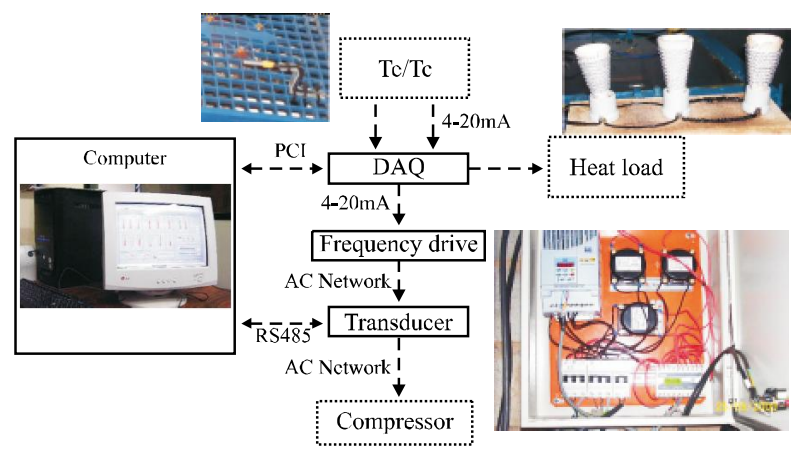

actuators and records data from all sensors, storing them in files for later analysis. Table 1 details the equipment used during the experiments.

Table 1 - Equipments used during the experiments

\begin{tabular}{lcc}
\hline \multicolumn{1}{c}{ Equipment } & Manufacturer & Model \\
\hline Compressor Hermetic, Alternative, R22 & Copeland & CS14K6E-TF5-522 \\
Evaporator & Macquay & FBA-190 \\
Condenser & Macquay & M4Q045-EF01-4 \\
Variable frequency drive & WEG & CFW080160T2024PSZ \\
Electrical parameters transducer & Kron & MultK-05 \\
\hline
\end{tabular}

\section{RESULTS AND DISCUSSION}

In order to determine the experimental conditions, the variables of interest were subjected to some preliminary tests. The average temperature outside the chamber during the tests was $18.9 \pm 0.4^{\circ} \mathrm{C}$, considering that when the compressor shuts down, the camera tends to stabilize at room temperature. This temperature was established as zero standards. Preliminary tests showed that with a heat load of $1,430 \mathrm{~W}$ and with compressor driven at $60 \mathrm{~Hz}$, the system reached the dynamic equilibrium at open loop cycle, remaining within its operational limits. Then, with a heat load of $1,430 \mathrm{~W}$ and the compressor operating at standard speed, Te stabilized at $21.8^{\circ} \mathrm{C}$ below ambient temperature, Tc at $19.4{ }^{\circ} \mathrm{C}$, also below ambient temperature. By this time, it was established $\Delta \mathrm{Te}_{\max }=-21.8{ }^{\circ} \mathrm{C}$ and $\Delta \mathrm{Tc}_{\max }=-19.4{ }^{\circ} \mathrm{C}$.
In order to identify the parameters of the blocks whose inputs is the frequency, the heat load was set at $1430 \mathrm{~W}$ and the compressor driving frequency was increased from 40 to $50 \mathrm{~Hz}$, which means $16.7 \%$ of $\Delta \mathrm{F}_{\text {máx }}(60 \mathrm{~Hz})$. This step in the frequency value was established in order to produce a variation in temperature Te with the same magnitude observed in the on-off controller originally installed in the system. All tests were conducted with four replications.

Figure 3 shows the experimental and simulated results for the proposed model, related to the output variables Te, Tc and $\mathrm{P}$ due to a step from 40 to $50 \mathrm{~Hz}$ in the compressor driving frequency. Figure $3 \mathrm{a}$ shows the experimental response of Te, observing that $\Delta \mathrm{Te}$ was $-2.3^{\circ} \mathrm{C}$, which means $10.5 \%$ of $\Delta \mathrm{Te}_{\max }$. Equation 12 shows the transfer function block $\mathrm{G}_{\mathrm{F}_{-} \mathrm{Te}}(\mathrm{s})$.

$$
G_{F-T e}(s)=\frac{T e}{F}=\frac{-0.63 e^{-15 s}}{916 s+1}
$$


Model $\mathrm{G}_{\mathrm{F}-\mathrm{Te}}(\mathrm{s})$ showed a maximum error of $0.11^{\circ} \mathrm{C}$ in the estimation of Te compared to the experimental result.

Figure $3 \mathrm{~b}$ shows the simulated response of Tc for the same amount of excitation in the driving frequency.
A $\Delta \mathrm{Tc}$ of $-2.1{ }^{\circ} \mathrm{C}$ was observed, which means $10.8 \%$ of $\Delta \mathrm{Tc}_{\max }$. Then, the transfer function for the block $\mathrm{G}_{\mathrm{F}_{-} \mathrm{Tc}}(\mathrm{s})$ was calculated according to Equation 13.

Figure 3 - Behavior of output variables due to a step function from 40 to $50 \mathrm{~Hz}$ in the compressor driving frequency: (a) Output Variable Te, (b) Output Variable Tc and (c) Output Variable P
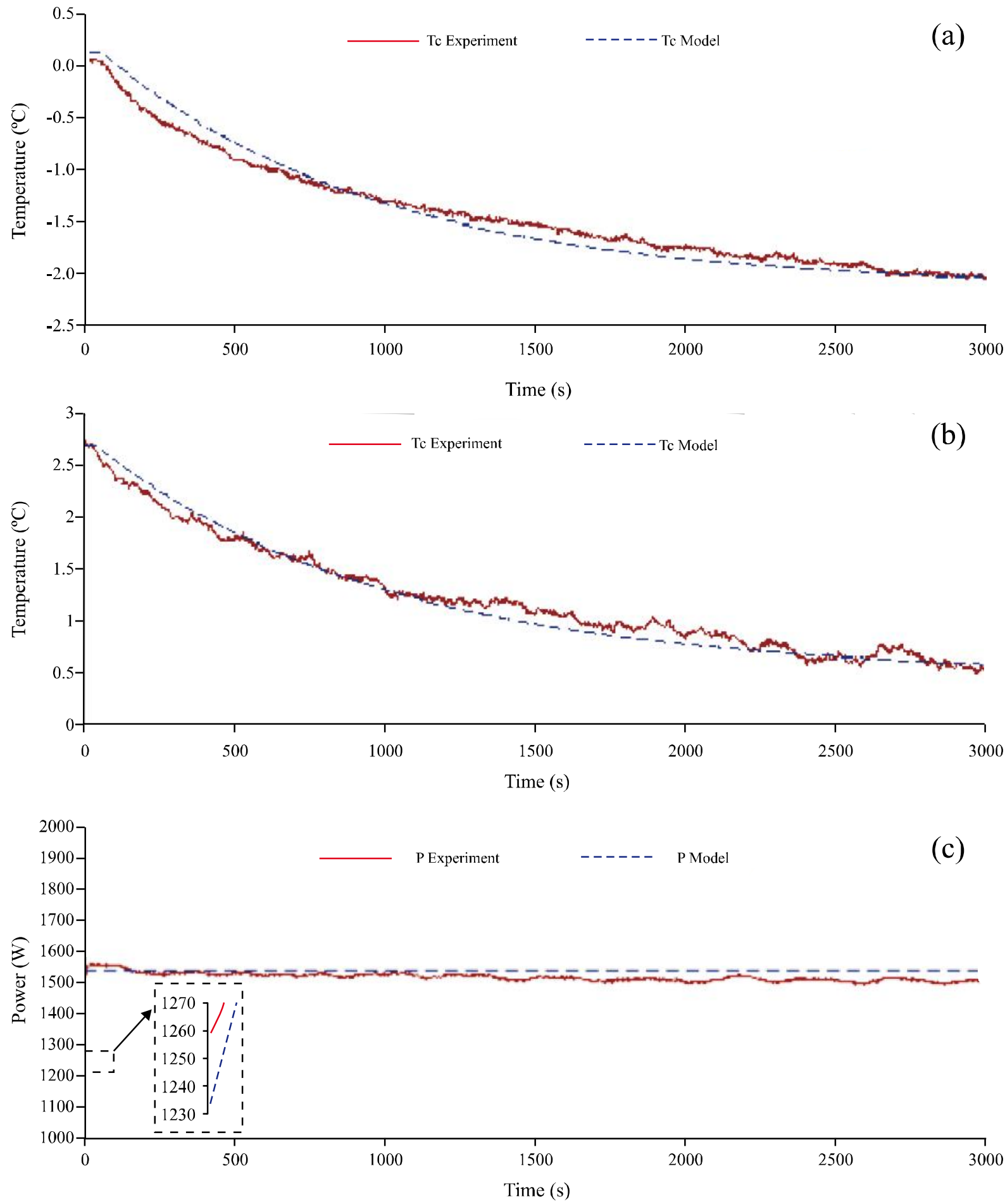


$$
G_{F-T c}(s)=\frac{T c}{F}=\frac{-0.66 e^{-35 s}}{967 s+1}
$$

The model $\mathrm{G}_{\mathrm{F}_{\mathrm{T}} \mathrm{Tc}}(\mathrm{s})$ showed a maximum error of $0.09{ }^{\circ} \mathrm{C}$ in the estimation of Tc compared to the experimental result.

For a compressor driving frequency of $60 \mathrm{~Hz}$, the average power consumption was $1903 \mathrm{~W}$. For the applied step in frequency (from 40 to $50 \mathrm{~Hz}$ ) power raised from 1233 to $1524 \mathrm{~W}$, generating an increase of $290 \mathrm{~W}$ which means $15.3 \%$ of total variation. Keeping the experimental condition, Figure $3 \mathrm{c}$ shows the behavior of $\mathrm{P}$ obtained experimentally and calculated by the model, using the gain of the block $\mathrm{G}_{\mathrm{F}_{\mathrm{P}} \mathrm{P}}(\mathrm{s})$, according to Equation 14. In this case, the maximum error for the model was $1.4 \%$.

$$
G_{F-P}(s)=\frac{P}{F}=0.91
$$

Applying the same technique to identify the models whose input is the heat load (C), the driving frequency was fixed at $45 \mathrm{~Hz}$ and a step in the heat load was applied from 1790 to $2860 \mathrm{~W}$. In these experiments $\Delta \mathrm{Te}_{\max }$ was $2.6^{\circ} \mathrm{C}$ and $\Delta \mathrm{Tc}_{\text {max }}$ was $4.5^{\circ} \mathrm{C}$.

The amplitude of the thermal load step was determined in order to generate on Te, approximately, the same temperature variation generated by the step on $\mathrm{F}$.

Figure 4 shows the experimental and simulated results for the proposed models, related to the output variables Te, Tc and $\mathrm{P}$ due to the thermal load step in the system. Figure 4a shows the behavior of Te, both experimental and simulated for the heat load step applied.

From the analysis of the measured values, it was possible to identify the transfer function of Equation 15. In this case, the average error of the model was $0.04{ }^{\circ} \mathrm{C}$.

$$
G_{C-T e}(s)=\frac{T e}{C}=\frac{0.15 e^{-42 s}}{960 s+1}
$$

In order to identify the parameters of the transfer function block $\mathrm{G}_{\mathrm{C}_{-} \mathrm{Tc}}(\mathrm{s})$ represented by Equation 16, the curve of the experimental behavior for the variation of Tc, shown in Figure 4b, was used. In this case, the adjusted model showed an average error of $0.05^{\circ} \mathrm{C}$ and its response is also presented in Figure $4 \mathrm{~b}$.

$$
G_{C-T c}(s)=\frac{T c}{C}=\frac{0.25 e^{-15 s}}{799 s+1}
$$

The transfer function for the block $\mathrm{G}_{\mathrm{C} \mathrm{p}}(\mathrm{s})$ (Equation 17) had its parameters identified based on the experimental response of $\mathrm{P}$, which curve is shown in Figure 4c. Also, Figure 4c shows the result obtained by the fitted model, with an average error of $\pm 6.5 \%$. However, for the real system, a consumption of 1794 $\mathrm{kWh}$ was calculated for the power consumed by the compressor in 5000 seconds. Integrating in the same period, the result obtained by the model for the output $\mathrm{P}$ was $1792 \mathrm{kWh}$, which represents an error of less than $1 \%$ in energy consumed.

$$
G_{C-P}(s)=\frac{P}{C}=\frac{0.06 e^{-182 s}}{1341 s+1}
$$

Considering the gains, it can be seen that temperatures are 4.4 times more sensitive to changes in the compressor drive frequency than in relation on the variation of the heat load. It was also noted that the power consumed is affected by $6 \%$ when the system undergoes a variation of heat load.

These results support the possibility of dividing the system into parts, and this was provided by the literature (ZHAO; ZAHEERUDDIN, 2005; MACKINLEY; ALLEYNE, 2008; LI; ALLEYNE, 2010). The model proved the first order approximation with time delay between the input variables ( $\mathrm{F}(\mathrm{s})$ e $\mathrm{C}(\mathrm{s}))$ and output variables $(\mathrm{Te}(\mathrm{s}), \mathrm{Tc}(\mathrm{s}))$. This approximation was also related by Aprea and Renno (2001), Aprea and Renno (2009), Ding (2006) e Hua, Jeong and Yoon (2007). The use of the sum of effects predicted by the model proved to be valid, due, mainly, to the interdependence between the variables, which was verified by experimental data. The numerical models proposed in this work (GF_P(s) e GC_P(s)), compared to the available literature, consider the estimation of the power consumed related to frequency, as well as the heat load imposed on the system. The deviations between the experimental results and those obtained with the model were considered satisfactory, as adopted by Hua, Jeong and Yoon(2007), Aprea and Renno (2001) and Costa, Leal and Carmo Júnior (2004), who admitted as acceptable errors in the range of $0.5^{\circ} \mathrm{C}$ at $1{ }^{\circ} \mathrm{C}$. These results establish a basis for further studies of control strategies in order to maintain a constant temperature inside the chamber with minimal energy consumption. 
Figure 4 - Behavior of the output variables as a function of one step from 1790 to $2860 \mathrm{~W}$ in heat load: (a) Output Variable Te, (b) Output variable Tc and (c) Variable output P
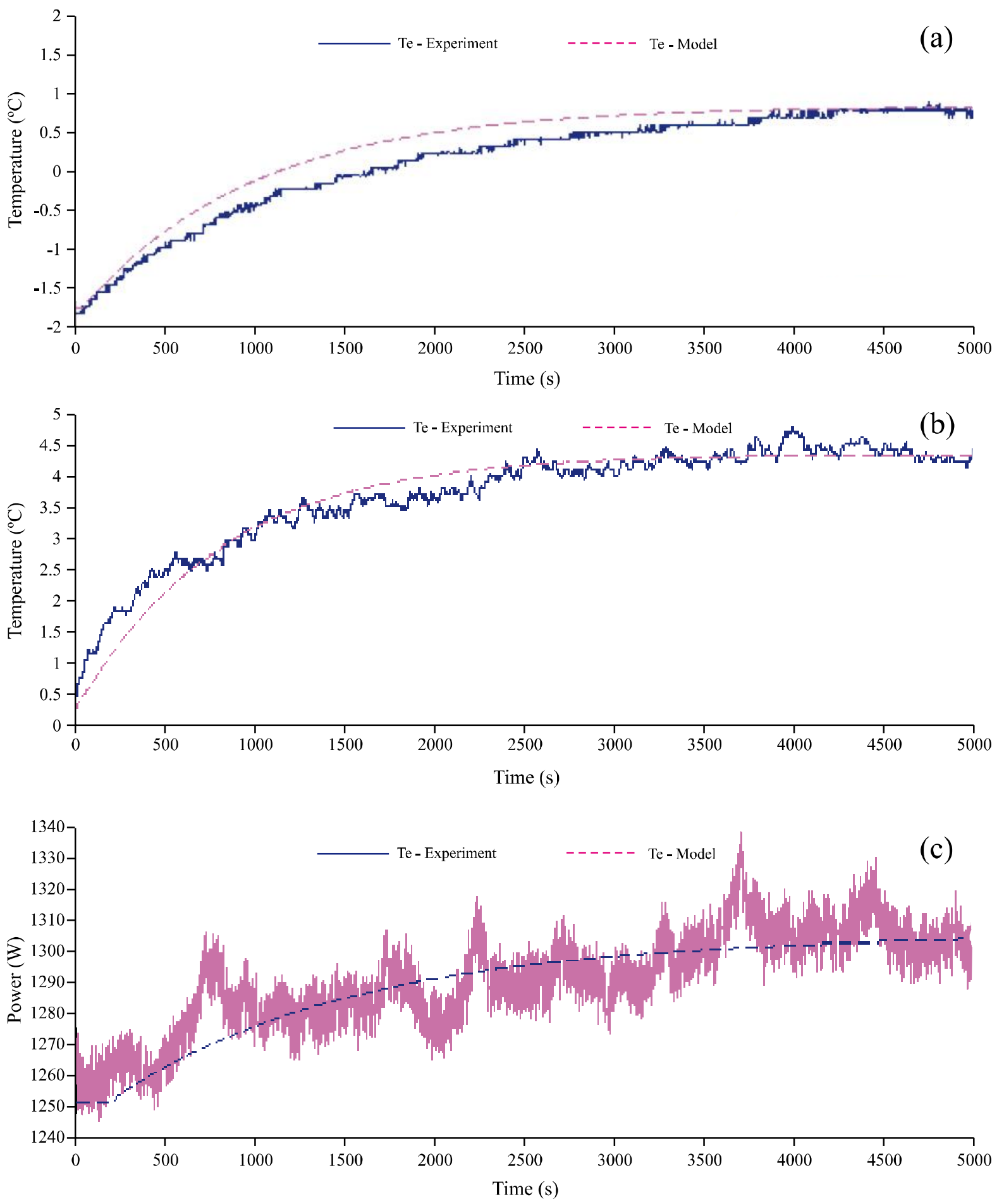

\section{CONCLUSIONS}

1. This study presented a numerical model with simple structure and easy identification by using transfer functions of first order with time delay and sum of effects between the variables;

2. The identification and validation of the block $G_{C}$ ${ }_{\mathrm{p}}(\mathrm{s})$ indicates that, even in open loop, the heat load 
directly influences the power consumption of the compressor;

3. The structure and the interdependence between the input and output variables were confirmed by the results obtained during the models validation. The resulting errors are considered satisfactory, less than $0.11{ }^{\circ} \mathrm{C}$ for Te, smaller than $0.09{ }^{\circ} \mathrm{C}$ for $\mathrm{Tc}$ and lower than $1 \%$ for the energy consumed;

4. The model was shown to be suitable for studies on control strategies in refrigeration systems in order to explore the dynamics of temperature and reducing energy consumption.

\section{REFERENCES}

APREA, C.; RENNO C. Experimental analysis of a transfer function for an air cooled evaporator. Applied Thermal Engineering, v. 21, n. 4, p. 481-493, 2001.

APREA, C.; RENNO C. Experimental model of a variable capacity compressor. International Journal of Energy Research, v. 33, n. 1, p. 29-37, 2009.

CHITARRA, M. I. F.; CHITARRA, A. B. Pós-colheita de frutos e hortaliças: fisiologia e manuseio. 2. ed. rev. e ampl. Lavras: UFLN, 2005. $783 \mathrm{p}$.

CORTEZ, L. A. B.; HONÓRIO, S. L.; MORETTI, C. L. Resfriamento de frutas e hortaliças. Brasília: Embrapa Hortaliças, 2002.

COSTA, E.; LEAL, P. E.; CARMO JÚNIOR, RUY R. . Modelo de simulação da temperatura e umidade relativa do ar no interior de estufa plástica. Engenharia Agrícola, v. 24, n. 1, p. 57-67, 2004.

CUEVAS, C. ; LEBRUN, J. . Testing and modelling of a variable speed scroll compressor. Applied Thermal Engineering, v. 29, n. 2/3, p. 469-478, 2009.

DING, G. Simulation technology for refrigeration and air conditioning appliances. Chinese Science Bulletin, v. 51, n. 16, p. 1913-1928, 2006.

EKREN, O.; SAHIN, S.; ISLER, Y. Comparison of different controllers for variable speed compressor and electronic expansion valve. International Journal of Refrigeration, v. 33, n. 6, p. 1161-1168, 2010.

HUA, L.; JEONG, S. K.; YOON, J. I.; YOU, S. S. An empirical model for independent control of variable speed refrigeration system. Applied Thermal Engineering, v. 28, n. 14/15, p. 1918-1924, 2007.
HUA, L.; JEONG, S. K.; YOU, S. S. Feedforward control of capacity and superheat for a variable speed refrigeration system. Applied Thermal Engineering, v. 29, n. 5/6, p. 1067-1074, 2008.

LI, B.; ALLEYNE, A. G. A dynamic model of a vapor compression cycle with shut-down and start-up operations. International Journal of Refrigeration, v. 33, n. 3, p. 538$552,2010$.

MACKINLEY, T. L.; ALLEYNE, A. G. An advanced nonlinear switched heat exchanger model for vapor compression cycles using the moving-boundary method. International Journal of Refrigeration, v. 31, n. 7, p. 1253-1264, 2008.

MENEGHETTI, C. R. et al. System for Studies of Control Strategies Applied in Refrigerated Chambers. In: CONGRESSO LATINOAMERICANO Y DEL CARIBE DE INGENIERÍA AGRÍCOLA, 9.; CONGRESSO BRASILEIRO DE ENGENHARIA AGRÍCOLA,39., 2010, Vitória Anais. Jaboticabal: REA, 2010. p. 1-8. v. 14.

MORINI, G. L.; PIVA, S. The simulation of transients in thermal plant. Part I: Mathematical model. Applied Thermal Engineering, v. 27, n. 11/12, p. 2138-2144, 2007.

MORINI, G. L.; PIVA, S. The simulation of transients in thermal plant. Part II: Applications. Applied Thermal Engineering, v. 28, n. 2/3, p. 244-251, 2008.

NOGUEIRA, C.E. C.; ZÜRN, H. H. Modelo de dimensionamento otimizado para sistemas energéticos renováveis em ambientes rurais. Engenharia Agrícola, v. 25, n. 2, p. 341-348, 2005

PIROZZI, D. C. Z.; AMENDOLA, M. Mathematical model and numerical simulation of strawberry fast cooling with forced air. Engenharia Agrícola, v. 25, n. 1, p. 222-230, 2005.

QURESHI, T.; TASSOU, S. Variable speed capacity control in refrigeration systems. Applied Thermal Engineering, v. 16, n. 2, p. 103-113, 1996.

SILVA, F. V. Comparison of the system performance for liquid refrigeration, controlled cooling the different ways of control. 2003. 327 f. Tese (Doutorado em Engenharia de Alimentos) - Faculdade de Engenharia de Alimentos, Universidade Estadual de Campinas, Campinas, 2003.

TIZZEI, A. et al. System for Studies of Control Strategies Applied in Refrigerated Chambers. Engenharia Agrícola, v. 31, n. 5, p. 868-878, 2011.

ZHAO, L.; ZAHEERUDDIN, M. Dynamic simulation and analysis of a water chiller refrigeration system, Applied Thermal Engineering, v. 25, n. 14/15, p. 2258-2271, 2005. 